\title{
Research on Sustainable Development of Library Consortia Based on Internet Plus
}

\author{
Chen $\mathrm{Li}$ \\ East China University of Technology \\ Nanchang, China
}

\begin{abstract}
The Internet Plus era provides more opportunities for the construction of library consortia. Based on the current situation of library consortia construction and the statistic data of literature in National Consortia of Library Reference Service and Changbei Academic Library Alliance, two issues are analyzed which are the characteristics of change in quantity of paper demanded by the society and the service ability of library consortia at present. The results indicate that the service level of library consortia under the background of Internet Plus has nearly increased five percent. Finally, the strategies are researched about the construction and development of library consortia under the background of Internet Plus.
\end{abstract}

Keywords—library consortia; Internet Plus; strategies

\section{INTRODUCTION}

Just as its name implies, library consortia refer to the set of libraries that sign cooperation agreement. It is an innovative measure in order to adapt to the network environment required by the international library circle. There are more than 150 members in the International Coalition of Library Consortia (OCOLC). There are many library consortia, exceeding 200 in America, let alone those not included in ICOLC [1]. In the era of network informatization, libraries must cooperate to survive. Therefore, the ways of cooperation become an important topic discussed by the library circle of many countries. The longterm practice has proved the best way of cooperation between libraries in the network era is to expand library consortia. Library consortia like CALIS have been established in our country. However, great gaps exist between developed country and our country in quantity and scale.

\section{ANALYSIS ON CURRENT SITUATION OF LIBRARY CONSORTIA CONSTRUCTION IN OUR COUNTRY}

At present, the library consortia construction in our country has made great achievements. Many characteristic library consortia have been established. However, problems exist in this process and influence the modernization construction of library in our country.

\section{A. Constraint of Traditional Thoughts}

The influence of traditional culture in our country is deeprooted. Although most of them are beneficial, conservative and outdated ideas still exist. Social progress and renewal of ideas realize in more than thirty years after the reform and opening up, but the thoughts such as "all his geese are swans" and "self-sufficiency" exist. It impedes the cooperation and coordination of libraries to a large extent [2]

\section{B. Absence of Unified Direction and Coordination}

Libraries are divided into public library and university library in the charge of cultural sector and education sector respectively. The division has adverse effect on the construction of library consortia. It goes against macro control, the coordination and unification of libraries and the crosssystem resource sharing. Resource construction and literature cataloguing repeat seriously. The development of automatic system and personalized service software in library lacks cooperation, leading to low level software and high repetitive rate of development and poor compatibility of system; libraries are engrossed in software development, the construction of thematic database and the construction of retrospective bibliographic database and lack overall planning. At present, the construction of library consortia carries out in many places of our country. It has appeared the trend that several centers exist in one area [3]

\section{Different Consortia}

Libraries are different according to different levels of economic development, so are library consortia. Funds and high-quality talents are necessary factors in allocation of advanced equipment and application of modern information technology. Libraries with sufficient funds and good foundation have higher degree of automation and modernization and smoother network construction. However, basic-level libraries with weak foundation and few funds focus on manual work and insufficient literature information resources, so they have more difficulties in network construction.

\section{Absence of Powerful Material Guarantee}

The restriction of funds greatly obstructs the construction of library consortia in our country, mainly reflecting in the development of software and hardware. In software, the construction of electronic information resources of our country is undeveloped. The database has small scale and small amount. Most information resources on the network are shown in English, which cause difficulties for people whose native language isn't English. In hardware, compared with developed countries, our country has narrow broadband of internet, obstructed channel of information resource transmission, 
leading to very slow information transfer rate that influences the utilization of information resources to a great extent [4-5].

\section{E. Fail to Adopt Corresponding National Standard}

Unified working routine, professional technical standard and efficient information exchange pattern are indispensable, in order to form network cooperation between libraries and the co-construction and sharing of information resources. However, most library consortia in our country have imperfect mechanism. Libraries lack the consciousness of cooperation and fail to roundly understand relevant network technology and haven't professional configuration software and hardware. The database construction is independent and lacks corresponding norms, seriously influencing the development of library consortia.

\section{F. Absence of High Quality Professional and Technical and Compound Talents}

The construction of library consortia has high requirements for technology. Librarians must be familiar with and utilize the existing resources as well as develop information resources [6]. However, demand of the comprehensive talents exceeds supply. Meanwhile, libraries fail to attract talents, leading to retarded construction of library consortia. Besides, the existing staffs lack modern network knowledge and operation technique. Therefore, the primary mission of library consortia construction is to solve manpower problems and strengthen talent training through multiple ways.

\section{G. Existence of Intellectual Property Dispute and Information Security Issues}

The construction of library consortia attaches inadequate importance to intellectual property, leading to intellectual property dispute. Some haven't been settled yet, such as the intellectual property protection of VPN and literature transmission. Information security issues exist in the process of information transmission, and there are no clear provisions of law on it. These urgent problems should be solved in the construction of library consortia.

\section{EMPIRICAL ANALYSES ON LIBRARY CONSORTIA SERVICE}

Literature transmission is the concentrated reflection of library consortia service. In order to further research the development mechanism of library consortia, the literature transfer data of ten representative library consortia are chosen to carry out statistic analysis. As shown in table 1, it [7] shows the society has great demand for literature resources. The quantity of request for papers in Guangzhou University of Chinese Medicine in one week reaches 4,919. Meanwhile, the service of library consortia fails to completely meet social demands. The highest fill rate of transmission reaches 95.1 percent. The overall service needs further improvement.

\section{TABLE I. TOP TEN OF SERVICE DATA OF LIBRARY CONSORTIA FROM OCT.17, 2016 TO ОСТ.23, 2016}

\begin{tabular}{|c|c|c|c|c|c|c|}
\hline No. & Library & $\begin{array}{l}\text { Chinese } \\
\text { (request) }\end{array}$ & $\begin{array}{c}\text { Transfer } \\
\text { (paper) }\end{array}$ & $\begin{array}{c}\text { Foreign } \\
\text { language } \\
\text { (request) }\end{array}$ & $\begin{array}{c}\text { Transfer } \\
\text { (paper) }\end{array}$ & $\begin{array}{c}\text { Percentage } \\
(\%)\end{array}$ \\
\hline 1 & $\begin{array}{l}\text { Guangzhou } \\
\text { University of } \\
\text { Chinese } \\
\text { Medicine }\end{array}$ & 4919 & 4679 & 789 & 733 & 94.8 \\
\hline 2 & $\begin{array}{l}\text { Sun Yat-sen } \\
\text { University }\end{array}$ & 2984 & 2838 & 352 & 327 & 94.9 \\
\hline 3 & $\begin{array}{l}\text { Sun Yat-sen } \\
\text { Library of } \\
\text { Guangdong } \\
\text { Province }\end{array}$ & 3148 & 2994 & 79 & 73 & 95.0 \\
\hline 4 & $\begin{array}{l}\text { Shenzhen } \\
\text { Library }\end{array}$ & 1905 & 1812 & 141 & 131 & 95.0 \\
\hline 5 & Jinan University & 1208 & 1149 & 485 & 450 & 94.4 \\
\hline 6 & $\begin{array}{c}\text { South China } \\
\text { Normal } \\
\text { University }\end{array}$ & 1005 & 956 & 479 & 445 & 94.4 \\
\hline 7 & $\begin{array}{c}\text { Foshan } \\
\text { University }\end{array}$ & 1024 & 974 & 127 & 118 & 94.9 \\
\hline 8 & $\begin{array}{l}\text { Dongguan } \\
\text { Library }\end{array}$ & 943 & 897 & 14 & 13 & 95.1 \\
\hline 9 & $\begin{array}{c}\text { Guangzhou } \\
\text { Library }\end{array}$ & 821 & 781 & 5 & 4 & 95.0 \\
\hline 10 & $\begin{array}{c}\text { Shenzhen } \\
\text { University City } \\
\text { Library }\end{array}$ & 594 & 565 & 97 & 90 & 94.8 \\
\hline
\end{tabular}

Furthermore, in the literature data statistics of library consortia [7], the quantity of literature request of Guangzhou University of Chinese Medicine ranks top. The library is chosen as the object to carry out the statistics of literature data in the first ten months of 2016. As shown in figure 1, the literature request has characteristics of temporal variation. The quantity of literature request is large at the beginning of the New Year. Moreover, the average quantity of literature request monthly in this library reaches 15,000 . The fill rate of literature transfer is a little bit less than the request quantity, so the service level of the library consortia needs improvement. 


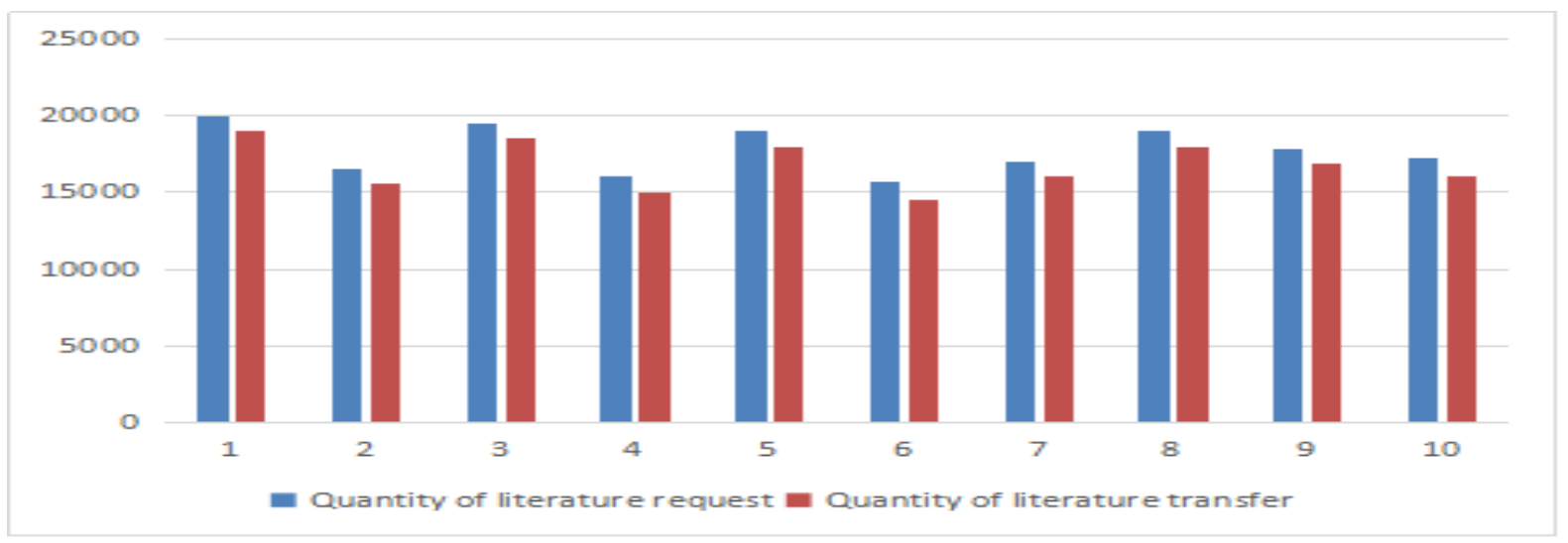

Fig. 1. Statistics of literature data in Guangzhou University of Chinese Medicine in 2016.

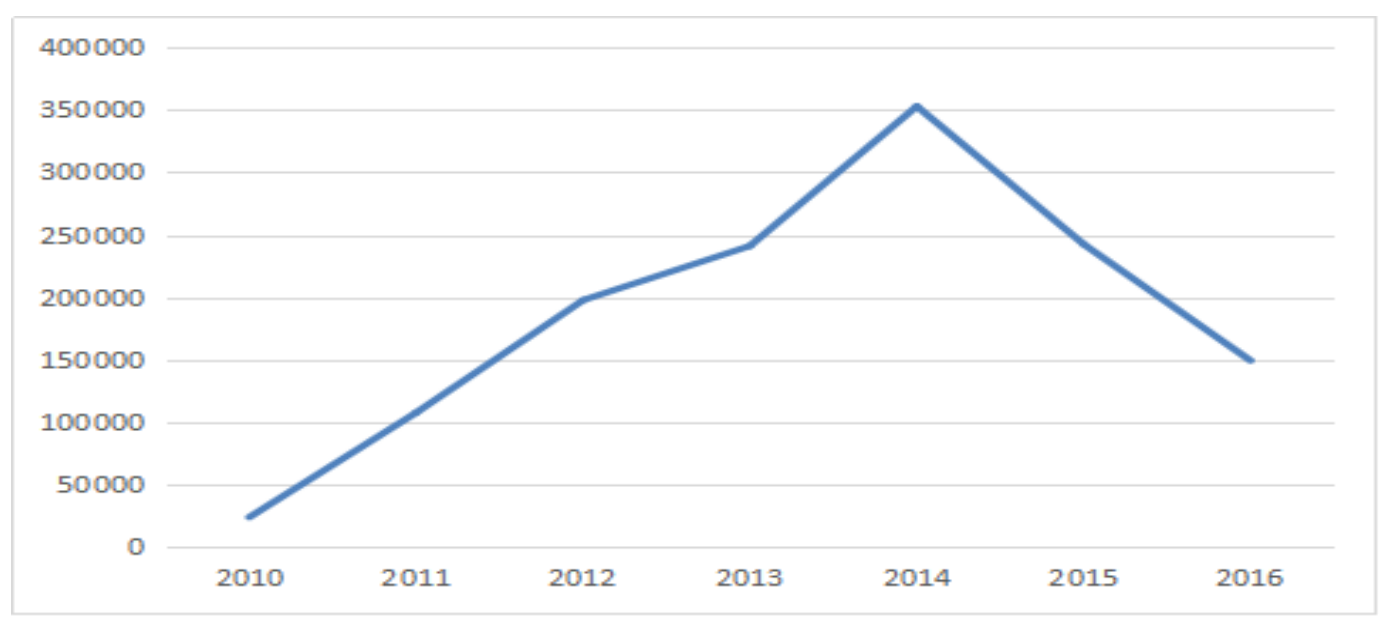

Fig. 2. Quantity of literature request in Changbei Academic Library Alliance from 2010 to 2016.

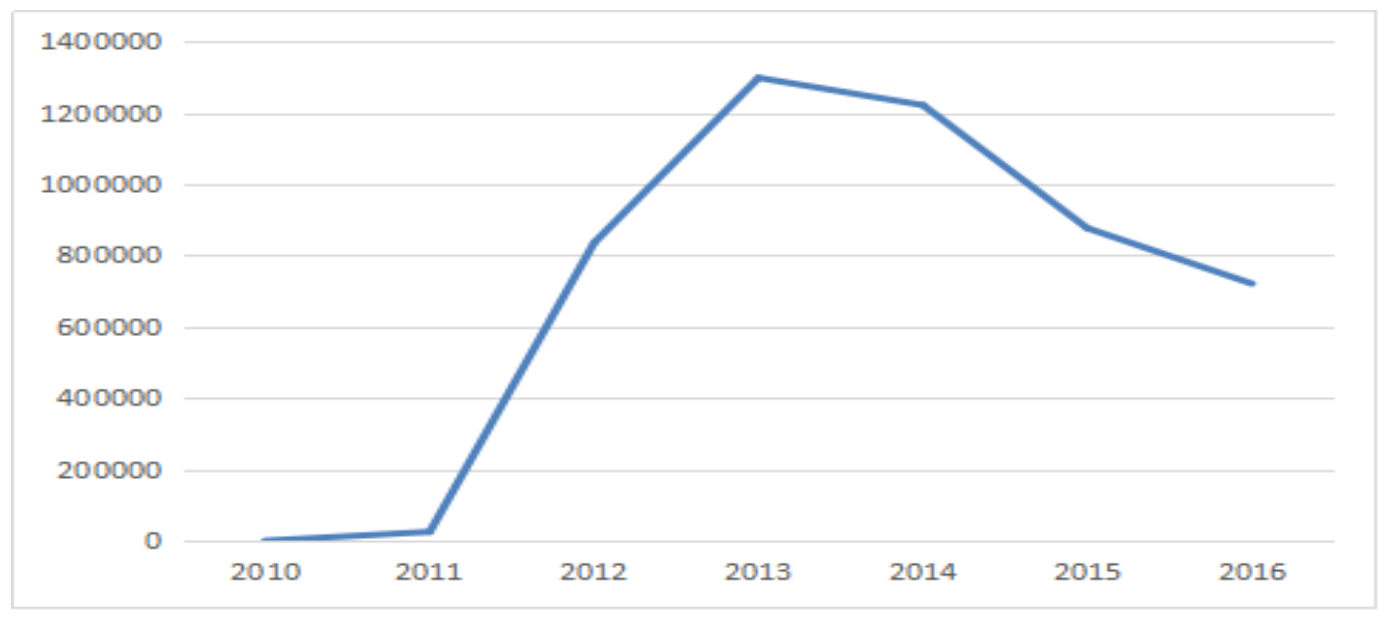

Fig. 3. Quantity of literature transfer in Changbei Academic Library Alliance from 2010 to 2016.

According to the data analysis of literature transfer in Changbei Academic Library Alliance from 2010 to September 2016, as shown in figure 2 and figure 3 , the quantity of literature request and transfer increases progressively year by year and peaks from 2013 to 2014, and then declines year by year. The relationship between the quantity of literature request and transfer is a criterion to measure the service ability of libraries. The quantity of literature request shows the demands of readers for literature information. The quantity of literature transfer is a measurement index of the service ability of libraries. As shown in figure 2, the quantity of literature request in Changbei Academic Library Alliance increases doubly from 2010 , reaches the peak of 350,000 in 2014 , but declines in the subsequent two years, less than the 
quantity of literature request in 2012. It indicates with the development of Internet Plus era, people have increasingly extensive channels to seek information, leading to the decline of quantity of literature request. The library service faces arduous tasks. Facing the challenge of increasingly diversified media, libraries should learn from others' strong points to offset their weakness and develop new service contents to meet people's diversified demands for literature information. As shown in figure 3, the quantity of literature transfer in Changbei Academic Library Alliance increases doubly from 2010 to 2013 and has decreased since 2013. Therefore, we should do our own job well, keep pace with the times and know information that attracts people's interests, carry out scientific and technological innovation and improve ability and level of service, in order to realize sustainable development of Changbei Academic Library Alliance.

\section{DisCUSSION ON STRATEGIES FOR SUSTAINABLE DEVELOPMENT OF LIBRARY CONSORTIA UNDER THE BACKGROUND OF INTERNET PLUS}

\section{A. Establish Guidance Center and Construct through Integrated Planning}

On national macro level, the construction of library consortia must have integrated planning and authoritative guidance. The co-construction and sharing of resources depends on cooperation of libraries at all levels in different places[8]. First, carry out integrated direction and planning instead of management through division. The Ministry of Information Industry is suggested to call on the establishment of library management department and system to manage libraries uniformly, and the guidance center of information resources to carry out professional guidance of library consortia. Second, establish regional center library through the country. The property and equipment of regional center library depends on economic development level, position and characteristics of resources. It plays a vital role in the construction of library consortia, providing resource guarantee and technical support for staff in the consortia as well as management, coordination and service. Third, establish unified working routine and adopt unified technical standard. Fourth, the government intensifies the investment to guarantee the material needs of library consortia construction.
Special funds are set up to promote the construction of regional center libraries.

\section{B. Raise Funds through Multiple Channels to Guarantee the Investment in Consortia}

The construction of library consortia is complicated. The corresponding capital investment is indispensable to serve readers. In order to construct modern library consortia, it is not enough to only depend on national investment. Libraries have to raise funds through various ways. The capital source includes: capitals distributed by the government, membership paid by member units, social sponsorship and donation. Library consortia should publicize to attract social attentions and strive for more support. Besides, libraries should improve their influence to attract investment from the society in fields that can obtain greater economic benefits. For example, vigorously develop commercial information products and service with high benefits.

\section{Normalize Construction Procedures and Build Consortia Standards}

Normalized technical standards are the primary condition to realize resource sharing among library consortia. The traditional library cooperation greatly impedes the communication among libraries and resource sharing because they fail to understand the collections of each other. Although computer, network, modern communication technology and united cataloguing are widely applied in libraries, the problem isn't solved thoroughly. The reason why library consortia cannot go smoothly is that the technical standards are not unified. Therefore, the normalized working standard especially the sound and unified technical standard is the important guarantee of successful library consortia. In order to solve these problems, libraries in the consortia should purchase uniform hardware equipment to develop library management system jointly. For example, in order to realize library consortia even international coalition, libraries use Z3950 protocol to carry out software development. The library consortia of Jilin province implements library consortia in Baicheng District and realizes standard service of all-purpose card, having gained good benefits. The results are shown in the following figure:

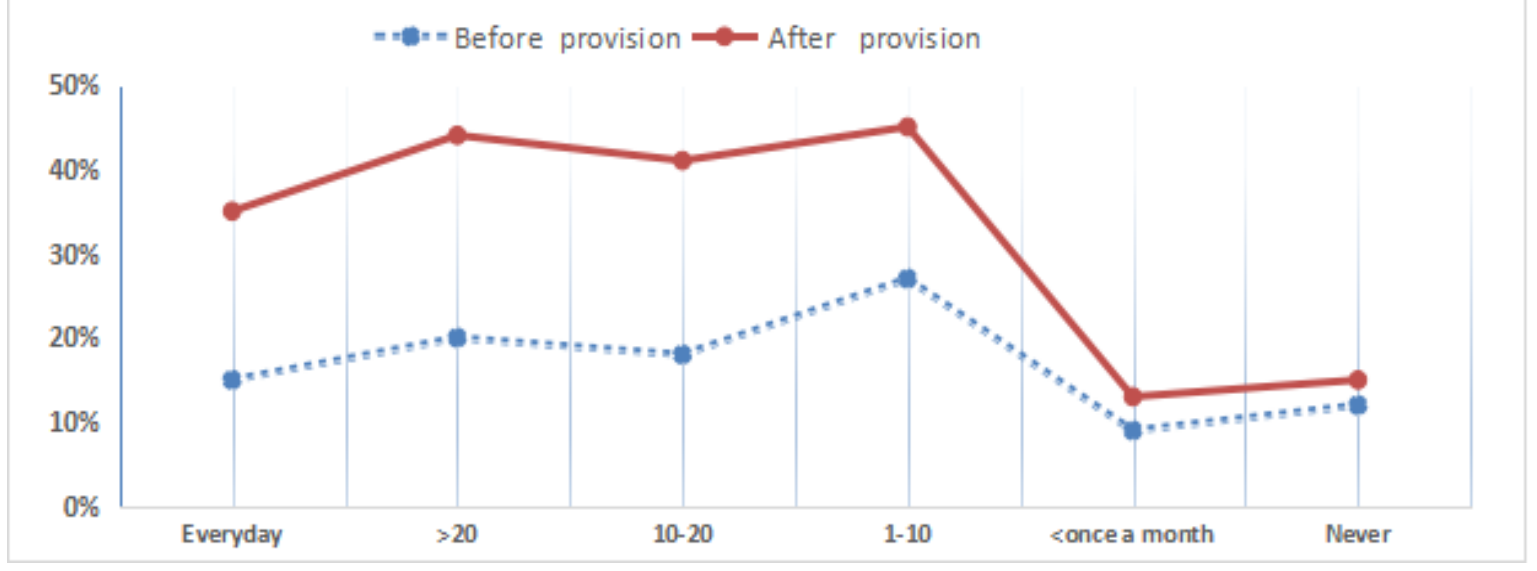

Fig. 4. Readers' utilization of library before and after provision of "all-purpose card". 
According to the above broken line graph, we can clearly see after the formation of library consortia in Baicheng District by library consortia of Jilin province, Baicheng District carries out promotion of service and all-purpose card, greatly improving readers' utilization rate of library. Readers who go there for eleven times per month account for a large proportion.

\section{Carry out Scattered Construction According to Physical Truth}

On the macro level, the construction of library consortia needs national integrated planning to reasonably and efficiently use resources in libraries. Meanwhile, libraries should take the initiative to develop characteristic resources [9]. At present, characteristic resource distribution and communication basis have formed in different regions, providing reality probability for scattered construction of library consortia. Therefore, in order to exploit the advantages of existing resources to the full, we must respect the reality and implement scattered construction. The different degree of economic development and the different quantity of literature request require us to construct library consortia.

\section{E. Plan Network Construction and Realize Sustainable Development}

Network is the basis of communication and necessity for communication of consortia. The network layout of library consortia must respect the original network of libraries and adopt technical interface to guarantee unblocked network of libraries. Because of different automatic system of libraries, data sharing realizes through network framework. Network construction means library consortia must realize sharing of resources through virtual collection and joint construction [10]. Network construction is the basis of library consortia and technical support of services, so it must fully consider the future development and use standardized technology to provide technical support for sustainable development of library consortia.

\section{F. Train Librarians to Improve Their Professional Quality}

People play a decisive role in all systems. Even the best library consortia need the promotion of people. Library consortia have new requirements for quality of librarians. Under the background of Internet Plus, except for accomplishments in computer, foreign language and professional language, librarians should learn new knowledge such as metadata and cloud computing to carry out service of library consortia. Libraries are growing, so library consortia related to library are constantly developing. New technology is applied to libraries continuously. At present, libraries face transformation and upgrading in our country and have higher requirements for librarian's quality. It is necessary to train librarians through many ways, in order to ceaselessly improve their professional level and service ability and better exert the function of library consortia.

\section{CONCLUSION}

In the development of library consortia, more librarians and curators realize the value and functions of librarian consortium. In addition, more readers enjoy the guarantee of information resources. Cross-regional, cross-industrial and compound library consortia emerge continuously. Library consortia have larger scale and more members, so the super library consortia produce. As an effective form of cooperation between libraries, library consortia will develop further.

\section{REFERENCES}

[1] Liang Xin. Mobile Library Consortia: Development Tendency of Information Resource Sharing in University Libraries [J], Information and Documentation Services, 2012, 02: 65-69

[2] Carlson S. Libraries' consortium conundrum [J].Chronicle of Higher Education, 2003, 50 (7):A30-A31

[3] Sun Yu, Sun Zhiquan. Thinking on Construction of Regional Library Consortia [J], Researches in Library Science, 2011, 08: 92-94+88

[4] Zhang Fu, Wu Xinnian, Zhang Hongli. Research on Construction and Development of Domestic Regional Library Consortia [J], Journal of Information, 2011, 08: 138-143+162

[5] Bai Bing, Gao Bo. Current Situation, Characteristics and Enlightenment of Resource Sharing in Libraries of Foreign Countries [J], Journal of Library Science in China, 2013,03:108-121

[6] Liu Xiaofeng, Li Yunbo. Research on Construction of Knowledge Sharing Platform in Regional Library under the Big Data Environment-Take the Library Consortia in Xinxiang of Henan Province as an Example [J], Journal of Library Science, 2015,07:25$29+33$

[7] National Consortia of Library Reference Services [DB].[2016-1025].http://www.ucdrs.net/admin/union/index.do

[8] Li Chen. Construction of Smart Service Pattern of Library [J], Heilongjiang Chronicles, 2013, 19: 221

[9] Chu Yuanli. Effects and Innovative Thinking of Information Resource Sharing Service in Universities of Heilongjiang [J], Library Theory and Practice, 2015, 08: 75-77

[10] Meng Ying. Opinions on Construction of Library Consortia under the Network Environment on Campus [J], China Health Industry, 2016, 01: $15-17$ 